\title{
Crizotinib as Salvage and Maintenance With Allogeneic Stem Cell Transplantation for Refractory Anaplastic Large Cell Lymphoma
}

\author{
James M. Cleary, MD, PhD; ${ }^{a}$ Scott Rodig, MD, PhD ; Paul M. Barr, MDc; Atul B. Shinagare, $\mathrm{MD}^{\mathrm{a}}$; \\ Jeffrey W. Clark, MD; Geoffrey I. Shapiro, MD, PhDa; and Philippe Armand, MDa
}

\begin{abstract}
The NPM-ALK fusion protein is found in $\mathrm{ALK}^{+}$anaplastic large cell lymphomas harboring the $t(2 ; 5)$ chromosomal translocation. Patients harboring ALK translocations typically have an excellent prognosis with conventional chemotherapy and a reported 5-year survival rate of $70 \%$. Although most patients with $\mathrm{ALK}^{+}$anaplastic large cell lymphoma have a good prognosis, some patients do not respond to standard therapies. In patients with refractory anaplastic large cell lymphoma who can achieve remission, allogeneic stem cell transplant is a potentially curative option. This article describes a patient with refractory $\mathrm{ALK}^{+}$anaplastic large cell lymphoma who experienced a complete response to the ALK inhibitor crizotinib and then underwent an allogeneic stem cell transplant followed by crizotinib maintenance therapy. ( $J$ Natl Compr Canc Netw 2014;12:323-326)
\end{abstract}

\section{NCCN: Continuing Education}

\section{Accreditation Statement}

This activity has been designated to meet the educational needs of physicians and nurses involved in the management of patients with cancer. There is no fee for this article. No commercial support was received for this article. The National Comprehensive Cancer Network (NCCN) is accredited by the ACCME to provide continuing medical education for physicians.

From a Dana-Farber Cancer Institute, Harvard Medical School and bBrigham and Women's Hospital, Harvard Medical School, Boston, Massachusetts; 'University of Rochester Medical Center, University of Rochester, Rochester, New York; and dMassachusetts General Hospital, Harvard Medical School, Boston, Massachusetts.

Submitted March 30, 2013; accepted for publication June 23, 2013.

The authors have disclosed that they have no financial interests, arrangements, affiliations, or commercial interests with the manufacturers of any products discussed in this article or their competitors.

Correspondence: James M. Cleary, MD, PhD, Dana-Farber Cancer Institute, Harvard Medical School, 450 Brookline Avenue, Boston, MA 02215. E-mail: jcleary@partners.org
NCCN designates this journal-based CME activity for a maximum of 1.0 AMA PRA Category 1 Credit(s) ${ }^{\mathrm{TM}}$. Physicians should claim only the credit commensurate with the extent of their participation in the activity.

NCCN is accredited as a provider of continuing nursing education by the American Nurses Credentialing Center's Commission on Accreditation.

This activity is accredited for 1.0 contact hours. Accreditation as a provider refers to recognition of educational activities only; accredited status does not imply endorsement by NCCN or ANCC of any commercial products discussed/displayed in conjunction with the educational activity. Kristina M. Gregory, RN, MSN, OCN, is our nurse planner for this educational activity.

All clinicians completing this activity will be issued a certificate of participation. To participate in this journal CE activity: 1) review the learning objectives and author disclosures; 2 ) study the education content; 3) take the posttest with a $66 \%$ minimum passing score and complete the evaluation at http://education.nccn.org/ node/41689; and 4) view/print certificate.

Release date: March 10, 2014; Expiration date: March 10, 2015

\section{Learning Objectives}

Upon completion of this activity, participants will be able to:

- Discuss the clinical activity of crizotinib in the management of patients with anaplastic large cell lymphoma

\section{EDITOR}

Kerrin M. Green, MA, Assistant Managing Editor, JNCCN-Journal of the National Comprehensive Cancer Network

Ms. Green has disclosed that she has no relevant financial relationships.

\section{CE AUTHORS}

Deborah J. Moonan, RN, BSN, Director, Continuing Education \& Grants Ms. Moonan has disclosed that she has no relevant financial relationships.

Ann Gianola, MA, Manager, Continuing Education \& Grants Ms. Gianola has disclosed that she has no relevant financial relationships. Kristina M. Gregory, RN, MSN, OCN, Vice President, Clinical Information Operations

Ms. Gregory has disclosed that she has no relevant financial relationships. 
The NPM-ALK fusion protein is found in $\mathrm{ALK}^{+}$ anaplastic large cell lymphomas harboring the $\mathrm{t}(2 ; 5)$ chromosomal translocation. ${ }^{1}$ Patients harboring ALK translocations typically have an excellent prognosis with conventional chemotherapy and a reported 5-year survival rate of $70 \% .^{2}$ Although most patients with $\mathrm{ALK}^{+}$anaplastic large cell lymphoma have a good prognosis, some do not respond to standard therapies. In patients with refractory anaplastic large cell lymphoma who can achieve remission, allogeneic stem cell transplant is a potentially curative option. ${ }^{3}$ In a retrospective analyses of 27 patients with anaplastic large cell lymphoma who underwent an allogeneic stem cell transplant, Le Gouill et $\mathrm{al}^{4}$ found a $55 \% 5$-year survival rate. This article describes a patient with refractory $\mathrm{ALK}^{+}$anaplastic large cell lymphoma who experienced a response to the ALK inhibitor crizotinib and underwent an allogeneic stem cell transplant. ${ }^{5}$

\section{Case Summary}

A 34-year-old man presented with lymphadenopathy and right arm edema. Pathology revealed anaplastic large cell lymphoma. Immunohistochemistry was positive for ALK1 and fluorescence in situ hybridization analysis demonstrated a $\mathrm{t}(2 ; 5)$ chromosomal translocation. The patient's anaplastic large cell lymphoma was refractory to standard treatment, and he progressed through 8 lines of chemotherapy in 11 months. The patient was unsuccessfully treated with CHOP, gemcitabine-based therapy, pralatrexate, high-dose methotrexate when he developed central nervous system (CNS) involvement, and brentuximab.

After these treatments, the patient was consented and enrolled in an experimental protocol testing crizotinib in patients with advanced cancers refractory to standard therapy (ClinicalTrials.gov identifier: NCT00585195). The trial was approved by the Dana-Farber/Harvard Cancer Center Institutional Review Board and was in accordance with the Declaration of Helsinki. At the time of enrollment, the patient had a large confluent mass that involved the entire lateral and posterolateral chest wall, and measured $13.4 \mathrm{~cm}$ in largest axial diameter and $30.5 \mathrm{~cm}$ in craniocaudal measurement. The patient reported that the mass was rapidly enlarging and extremely painful. His LDH level was elevated at $347 \mathrm{U} / \mathrm{L}$. On the experimental protocol, the patient was treated with crizotinib, $250 \mathrm{mg}$ twice a day. Crizotinib was well tolerated and no signs were seen of tumor lysis. Symptomatic improvement was seen within 3 days, and a restaging PET/CT scan performed 8 weeks later showed a complete metabolic response. Figure 1 shows a comparison of the baseline PET/CT scan (Figure 1A) with the PET/CT scan obtained after 8 weeks of crizotinib treatment (Figure 1B).

Thirteen weeks after starting crizotinib, the patient underwent a myeloablative hematopoietic stem cell transplant and received peripheral blood stem cells from a fully matched unrelated donor. Crizotinib was stopped a day before he started the conditioning regimen of cyclophosphamide and total body irradiation. The transplant was well tolerated, except for an episode of asymptomatic cryptogenic organizing pneumonia that responded to steroids. At 21 days after stem cell infusion, the patient was able to restart the experimental protocol of crizotinib. Upon restarting, the patient initially experienced transient thrombocytopenia. Titration of tacrolimus was challenging because of the drug interaction between tacrolimus and crizotinib (crizotinib is a CYP3A4 inhibitor). At the time of writing, it has been 33 months since the patient first started crizotinib. He has been on maintenance crizotinib for 30 months and is experiencing complete remission according to PET/CT.

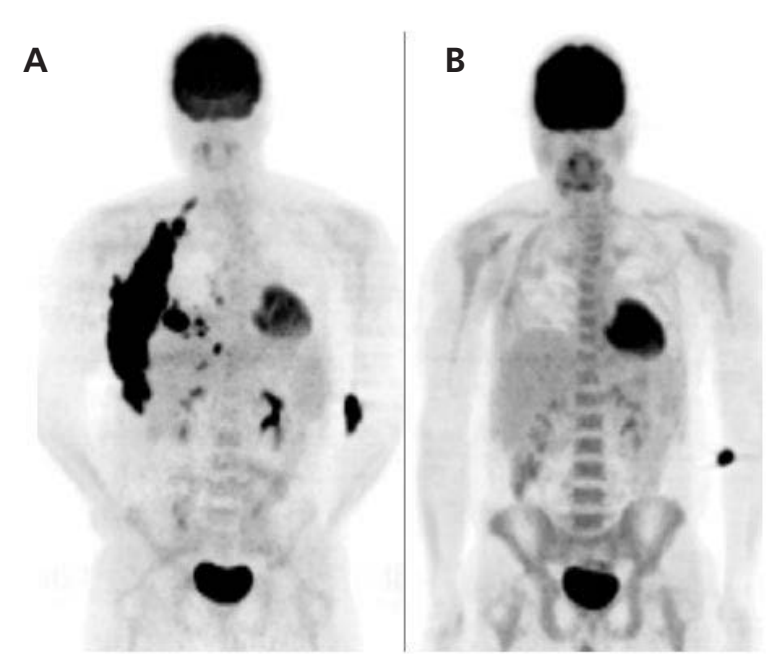

Figure 1 PET/CT scan at (A) baseline and (B) 8 weeks after crizotinib treatment. 


\section{Discussion}

Preclinical data have shown that ALK tyrosine kinase activity is essential to the survival of $\mathrm{ALK}^{+}$anaplastic large cell lymphoma cell lines. ${ }^{6}$ Consistent with this, case reports have shown the activity of crizotinib in $\mathrm{ALK}^{+}$anaplastic large cell lymphoma. ${ }^{7,8}$ In a pediatric phase I trial, 7 of 8 patients with anaplastic large cell lymphoma experienced a complete response after treatment with crizotinib. ${ }^{9}$ Similar to the present case, Ordemann et $\mathrm{al}^{8}$ reported a case in which crizotinib treatment followed by brentuximab served as a bridge to allogeneic stem cell transplant.

In the present patient, crizotinib did not interfere with the ability to perform an allogeneic stem cell transplant, and was safely reintroduced as maintenance therapy after transplant. This suggests the feasibility of using crizotinib as a bridge to allogeneic stem cell transplant and as maintenance therapy after transplant. Given the drug-drug interaction between crizotinib and tacrolimus, the dosage of tacrolimus must be carefully monitored in the posttransplant setting.

Seven months before starting crizotinib, the patient had evidence of lymphoma in his cerebrospinal fluid (CSF). He was treated with high-dose methotrexate and has had no evidence of CNS recurrence since that time. Interestingly, crizotinib does not seem to have a high penetrance into the CNS. Pharmacokinetic analysis of a patient with lung cancer treated with crizotinib showed that the concentration of crizotinib was much lower in the CSF than in the plasma. ${ }^{10}$ Consistent with this, the CNS is a frequent area of recurrence in patients with lung cancer treated with crizotinib. ${ }^{11,12}$

It is impossible to know the relative contributions of crizotinib and the allogeneic stem cell transplantation in this patient. In EML4-ALKrearranged non-small cell lung cancer, patients inevitably develop resistance to crizotinib, and the median progression-free survival in this population is 9.7 months. ${ }^{13}$ However, data on the long-term effectiveness of crizotinib in anaplastic large cell lymphoma are much more limited. A recent report by the Children's Oncology Group described 2 pediatric patients whose anaplastic large cell lymphoma continued to respond to crizotinib after treatment with the drug for at least 2 years. ${ }^{9}$ Data on the long-term effectiveness of allogeneic stem cell transplantation in patients with refractory anaplastic large cell lym- phoma are also limited. One case series showed that the 5-year survival rate for patients with anaplastic large cell lymphoma was 55\% after allogeneic stem cell transplantation. ${ }^{4}$

Therefore, the long remission obtained for the present patient could reflect ongoing disease control by crizotinib or a successful graft-versus-lymphoma effect. It is also possible that both therapies are contributing to the patient's long-term disease control.

Despite these encouraging responses in $\mathrm{ALK}^{+}$ anaplastic large cell lymphoma, whether other $\mathrm{ALK}^{+}$ lymphomas will have the same sensitivity is unclear. We have also treated a 29-year-old woman whose refractory $\mathrm{ALK}^{+}$large B-cell lymphoma rapidly progressed through treatment with crizotinib. ${ }^{14}$ Further investigation is needed to explore whether the crizotinib resistance seen in this patient is generalizable. It is possible that the ALK kinase domain plays different roles in the oncogenesis of $\mathrm{ALK}^{+}$large B-cell lymphoma and $\mathrm{ALK}^{+}$anaplastic large cell lymphoma.

\section{Conclusions}

New treatments for patients with refractory ALK $^{+}$ anaplastic large cell lymphoma are greatly needed. An emerging series of case reports suggests that crizotinib may be an effective treatment in this disease..$^{7-9}$ The present case report highlights the possibility of using crizotinib both as a bridge to allogeneic stem cell transplant and as maintenance therapy after transplant.

\section{References}

1. Morris SW, Kirstein MN, Valentine MB, et al. Fusion of a kinase gene, ALK, to a nucleolar protein gene, NPM, in non-Hodgkin's lymphoma. Science 1994;263:1281-1284.

2. Savage KJ, Harris NL, Vose JM, et al. ALK- anaplastic largecell lymphoma is clinically and immunophenotypically different from both ALK+ ALCL and peripheral T-cell lymphoma, not otherwise specified: report from the International Peripheral T-Cell Lymphoma Project. Blood 2008;111:5496-5504.

3. Woessmann W, Peters C, Lenhard M, et al. Allogeneic haematopoietic stem cell transplantation in relapsed or refractory anaplastic large cell lymphoma of children and adolescents-a Berlin-Frankfurt-Münster group report. $\mathrm{Br} \quad \mathrm{J}$ Haematol 2006;133:176-182.

4. Le Gouill S, Milpied N, Buzyn A, et al. Graft-versus-lymphoma effect for aggressive T-cell lymphomas in adults: a study by the Société Française de Greffe de Moëlle et de Thérapie Cellulaire. J Clin Oncol 2008 2008;26:2264-2271. 
Cleary et al

5. Kwak EL, Bang YJ, Camidge DR, et al. Anaplastic lymphoma kinase inhibition in non-small-cell lung cancer. N Engl J Med 2010;363:1693-1703.

6. Wan W, Albom MS, Lu L, et al. Anaplastic lymphoma kinase activity is essential for the proliferation and survival of anaplastic large-cell lymphoma cells. Blood 2006;107:1617-1623.

7. Gambacorti-Passerini C, Messa C, Pogliani EM. Crizotinib in anaplastic large-cell lymphoma. N Engl J Med 2011;364:775-776.

8. Ordemann R, Stohlmacher J, Beuthien-Baumann B, et al. Use of targeted therapy for refractory ALK-positive anaplastic large cell lymphoma as a bridging strategy prior to allogeneic transplantation. Ann Hematol 2013;92:125-127.

9. Mossé YP, Lim MS, Voss SD, et al. Safety and activity of crizotinib for paediatric patients with refractory solid tumours or anaplastic large-cell lymphoma: a Children's Oncology Group phase 1 consortium study. Lancet Oncol 2013;14:472-480.
10. Costa DB, Kobayashi S, Pandya SS, et al. CSF concentration of the anaplastic lymphoma kinase inhibitor crizotinib. J Clin Oncol 2011;29:e443-445.

11. Chun SG, Choe KS, Iyengar P, et al. Isolated central nervous system progression on crizotinib: an Achilles heel of non-small cell lung cancer with EML4-ALK translocation? Cancer Biol Ther 2012;13:1376-1383.

12. Maillet D, Martel-Lafay I, Arpin D, Perol M. Ineffectiveness of crizotinib on brain metastases in two cases of lung adenocarcinoma with EML4-ALK rearrangement. J Thorac Oncol 2013;8:e30-31.

13. Camidge DR, Bang YJ, Kwak EL, et al. Activity and safety of crizotinib in patients with ALK-positive non-small-cell lung cancer: updated results from a phase 1 study. Lancet Oncol 2012;13:1011-1019.

14. Morgan EA, Armand P, Cleary JM, et al. Anaplastic lymphoma kinase-positive large B-cell lymphoma: a rare tumor and a challenging diagnosis. Pathol Case Rev 2012;17:62-68.

\section{Instructions for Completion}

To participate in this journal CE activity: 1) review the learning objectives and author disclosures; 2 ) study the education content; 3 ) take the posttest with a $66 \%$ minimum passing score and complete the evaluation at http://education.nccn.org/ node/41689; and 4) view/print certificate. After reading the article, you should be able to answer the following multiple- choice questions. Credit cannot be obtained for tests completed on paper. You must be a registered user on NCCN.org. If you are not registered on NCCN.org, click on "New Member? Sign up here" link on the left hand side of the Web site to register. Only one answer is correct for each question. Once you successfully answer all posttest questions you will be able to view and/or print your certificate. Software requirements: Internet.

\section{Posttest Questions}

1. Most patients with $\mathrm{ALK}^{+}$anaplastic large cell lymphoma are curable with conventional chemotherapy.
a. True
b. False

2. Allogeneic stem cell transplant is a potentially curative option for patients with refractory anaplastic large cell lymphoma who can achieve a remission.
a. True
b. False

3. Which of the following is considered an adverse effect of crizotinib?

a. Asymptomatic cryptogenic organizing pneumonia

b. Transient thrombocytopenia

c. A and B

d. None of the above 